\title{
ФОРМИРОВАНИЕ И ОЦЕНКА ФУНКЦИОНАЛЬНОЙ ГРАМОТНОСТИ ШКОЛЬНИКОВ
}

\author{
Гурьянова Светлана Юрьевна \\ кандидат экономических наук, доцент \\ учитель истории и обществознания \\ МАОУ Домодедовский лицей №3 \\ им. Героя Советского Союза Ю.П. Максимова
}

\begin{abstract}
Аннотация: Статья посвящена актуальным проблемам формирования и оценки функциональной грамотности школьников. На примере МАОУ Домодедовский лицей №3 им. Героя Советского Союза Ю.П. Максимова, входящего в сто лучших школ Подмосковья за 2020-2021 учебный год, раскрывается практический опыт реализации «дорожной карты» по формированию и оценке функциональной грамотности обучающихся. Автором предложена дидактическая памятка для учителей по повышению уровня функциональной грамотности школьников, представляющая значительный интерес с точки зрения ее возможного внедрения в образовательный процесс.

Ключевые слова: PISA, функциональная грамотность, «дорожная карта», дидактическая памятка, комплексные задания.
\end{abstract}

\section{FORMATION AND EVALUATION OF FUNCTIONAL LITERACY OF SCHOOLCHILDREN}

\section{Guryanova Svetlana Yurievna}

\begin{abstract}
The article is devoted to the actual problems of formation and evaluation of functional literacy of schoolchildren. Using the example of the Domodedovo Lyceum No. 3 named after Hero of the Soviet Union Yu.P. Maximov, which is one of the hundred best schools in the Moscow region for the 2020-2021 academic year, the practical experience of implementing the "roadmap" for the formation and evaluation of functional literacy of students is revealed. The author has proposed a didactic memo for teachers on improving the level of functional literacy
\end{abstract}




\section{СОВРЕМЕННЫЕ ТЕХНОЛОГИИ:

of schoolchildren, which is of considerable interest from the point of view of its possible introduction into the educational process.

Key words: PISA, functional literacy, "road map", didactic memo, complex tasks.

С начала 2000-х годов наша страна принимает участие в международных программах исследования качества образования. Повышение места России в подобных рейтингах стало одной из целей национального проекта «Образование». В апреле 2022 года в РФ пройдет очередное крупное исследование «Programme for International Student Assessment» (PISA - 2022), итоги которого будут официально объявлены в декабре 2023 года. В рамках подготовки к этому событию и дальнейшему улучшению качества российского образования в 2019-2024 годах в Российской Федерации проводится оценка качества общего образования в общеобразовательных организациях на основе практики международных исследований качества подготовки обучающихся.

Результаты национальных исследований, проводимых в России, говорят о наличии серьезных проблем, связанных с уровнем профессионализма российских учителей. Например, проведенные Рособрнадзором исследования компетенций учителей русского языка, математики и литературы показали наличие проблем, как в части предметной подготовки учителей, так и при выполнении ими заданий на оценку методических компетенций.

Эти проблемы не могут быть решены только путем обновления системы квалификационных категорий, поскольку изменение категорий и способов аттестации само по себе не позволяет повысить уровень профессионализма. Необходимо развивать и современные формы наставничества, методической помощи учителям, имеющим проблемы [6].

Если посмотреть шире на круг вопросов, которые возникают в связи со сложившейся ситуацией, то для решения этих проблем необходима система непрерывного повышение уровня профессионального мастерства учителей. Помимо этого необходимо организовывать научно-практические конференции и марафоны для заинтересованных педагогов с целью более глубокого осмысления вопросов формирования и оценки функциональной грамотности. Учителя должны чаще встречаться на заседаниях ШМО и методических семинарах, открытых уроках и мастер-классах, дискуссионных клубах и вебинарах для обмена собственным опытом. Необходимо вовлекать учителей 
разных предметов в профессиональное сотрудничество для развития общепедагогических компетенций и разработки и внедрения в учебный процесс практико-ориентированных, нетривиальных, межпредметных, комплексных задач.

Используя эти мероприятия, образовательные организации Московской области смогли успешно пройти региональную «Оценку по модели PISA - 2021 (PISA for school)» основанную на проекте Организации экономического сотрудничества и развития (ОЭСР). Процедуры организации и проведения исследования были аналогичны оригинальному исследованию PISA, но позволили проводить исследование и получать данные вне расписания международных циклов.

В исследовательской выборке Московской области - 141 муниципальная и частная образовательные организации и 9 государственных. Результаты по математической, читательской и естественнонаучной грамотности основной доли школ региона выше общероссийских. Средние баллы по Московской области представлены в таблице 1 [7].

МАОУ Домодедовский лицей №3 им. Героя Советского Союза Ю.П. Максимова наряду с другими образовательными организациями принял участие в данном исследовании. Результаты по читательской, математической и естественнонаучной грамотности МАОУ Домодедовский лицей №3 им. Героя Советского Союза Ю.П. Максимова выше результатов Московской области и общероссийской оценки, проведенной в 2020 г.

Таблица 1

\section{Результаты региональной оценки}

по модели PISA - 2021 (PISA for schools) [7]

\begin{tabular}{|l|c|c|c|c|c|c|}
\hline & \multicolumn{5}{|c|}{ Грамотность } \\
\cline { 2 - 7 } & \multicolumn{2}{|c|}{ Читательская } & \multicolumn{2}{|c|}{ Математическая } & \multicolumn{2}{|c|}{$\begin{array}{c}\text { Естественно- } \\
\text { научная }\end{array}$} \\
\cline { 2 - 7 } & Балл & Место & Балл & Место & Балл & Место \\
\hline $\begin{array}{l}\text { МАОУ Домодедовский } \\
\text { Лицей №3 }\end{array}$ & 585 & - & 651 & - & 541 & - \\
\hline Московская область & 527 & 3 & 549 & 5 & 501 & 19 \\
\hline Россия & 492 & 24 & 494 & 27 & 472 & 36 \\
\hline
\end{tabular}




\section{СОВРЕМЕННЫЕ ТЕХНОЛОГИИ:

В нашей образовательной организации разработана «дорожная карта», направленная на формирование и оценку функциональной грамотности обучающихся. Цель «дорожной карты» - создать условия для формирования и развития функциональной грамотности учащихся лицея.

«Дорожная карта» включает в себя следующие элементы [4]:

1. Знакомство всех педагогов с федеральными нормативно-правовыми актами и методическими материалами по вопросам формирования и оценки функциональной грамотности школьников.

2. Разработка плана по формированию функциональной грамотности школьников и локальных актов, которые обеспечивают его реализацию.

3. Создание школьной команды по формированию функциональной грамотности обучающихся.

4. Проведение классными руководителями разъяснительных родительских собраний по тематике метапредметных результатов ФГОС в контексте международного исследования PISA.

5. Оценка качества методической работы с педагогами по вопросам формирования функциональной грамотности школьников.

6. Проверка наличия в учебных планах каждой параллели спецкурсов и элективных курсов, которые направлены на формирование функциональной грамотности школьников.

7. Контроль наличия учебных пособий, которые помогут учителям работать над формированием функциональной грамотности школьников.

8. Совершенствование содержания учебно-методического комплекса и форм преподавания для развития функциональной грамотности обучающихся.

9. Пополнение и актуализация банка заданий и межпредметных технологий для формирования функциональной грамотности обучающихся.

Хочу остановиться на некоторых деталях этой карты на примере работы учителей истории МАОУ Домодедовский лицей №3 им. Героя Советского Союза Ю.П. Максимова.

Педагоги нашего лицея прошли обучение по программе повышения квалификации «Развитие компетенций педагога по формированию и оценке компонентов функциональной грамотности обучающихся» (72 ч) в ГБОУ ВО МО «Академия социального управления».

Учителя истории преподают различные элективные курсы, направленные на развитие отдельных видов функциональной грамотности, например 
элективный курс «История в лицах» формирующий читательскую грамотность, элективный курс «Финансы: просто о сложном» формирующий финансовую грамотность учащихся и др. [2].

Основным инструментом для формирования и оценки функциональной грамотности наших учеников являются практико-ориентированные комплексные задания, объединенные в тематические блоки. Как правило, блок заданий включает в себя описание реальной ситуации, представленное, в проблемном ключе, и ряд вопросов-заданий, относящихся к этой ситуации. Учащиеся выполняют эти нетривиальные задания, используя знания и навыки из различных предметных областей. Последовательное выполнение таких заданий от простого к сложному, способствует тому, что двигаясь от вопроса к вопросу, ученики погружаются в описанную ситуацию и применяют свои знания и умения, а также вырабатывают и закрепляют новые «навыки XXI века» (например, совместное решение проблем), необходимые для жизни в современном обществе.

В своей работе мы используем открытые банки заданий для формирования и оценки функциональной грамотности учащихся с учетом подходов и инструментария международного исследования PISA:

1. Банк заданий для формирования и оценки функциональной грамотности обучающихся основной школы (5-9 классы) на сайте ФГБНУ ИСРО РАО (http://skiv.instrao.ru/bank-zadaniy/).

2. Электронный банк заданий для оценки функциональной грамотности на сайте РЭШ (https://fg.resh.edu.ru/).

3. Задания для 5-9 классов по истории, обществознанию др. для развития письменной речи ФГБНУ «ФИПИ» (https://fipi.ru/metodicheskaya-kopilka/ zadaniya-dlya-5-9-klassov).

4. Банк заданий по функциональной грамотности для учеников 1 9 классов издательства «Просвещение» (https://media.prosv.ru/fg/).

5. Банк заданий (цифровые тренажеры PISA-2021) по развитию функциональных компетенций обучающихся издательства цифрового контента «ФИЗИКОН» (https://mo.imumk.ru/school/).

6. Банк заданий по функциональной грамотности образовательной онлайн-платформы «Учи.py» (https://uchi.ru/) и др. 


\section{СОВРЕМЕННЫЕ ТЕХНОЛОГИИ: ТЕНДЕНЦИИ И ПЕРСПЕКТИВЫ РАЗВИТИЯ}

Указанные банки заданий, по разным видам функциональной грамотности, охватывают все основные предметы школьной программы и постоянно пополняются.

Особо подчеркнем, что учителя истории МАОУ Домодедовский лицей №3 им. Героя Советского Союза Ю.П. Максимова, изучив методические рекомендации и примеры готовых открытых заданий, разработанные российскими и зарубежными специалистами из научных центров и институтов, начали создавать и внедрять в учебный процесс собственные комплексные задания по формированию функциональной грамотности учащихся [1].

Например, мы самостоятельно разрабатываем собственные комплексные и контекстные практико-ориентированные задания по актуальным проблемам и наиболее сложным вопросам курса истории, а также пошаговые инструкции по их выполнению. Педагоги нашего лицея понимают, что учителя должны помочь своим ученикам сформировать функциональную грамотность и наилучшим образом подготовиться к внешним исследованиям и внутренним диагностикам. Тем более что учебный курс истории обладает широчайшими возможностями для этого.

Справиться со столь сложной и ответственной задачей мне, как учителю истории, помогает разработанная, апробированная и внедренная мной в учебный процесс дидактическая памятка для учителя по формированию и оценке функциональной грамотности школьников на уроках истории.

Памятка содержит следующие разделы:

Раздел 1. ЗНАЙ, что:

Термин «функциональная грамотность» введен ЮНЕСКО в 1957 году.

По мнению А.А. Леонтьева, «функционально грамотный человек - это человек, который способен использовать все постоянно приобретаемые в течение жизни знания, умения и навыки для решения максимально широкого диапазона жизненных задач в различных сферах человеческой деятельности, общения и социальных отношений» [5].

Основными направлениями функциональной грамотности являются: читательская грамотность (поиск информации, понимание информации, осмысление и оценка информации), математическая грамотность (умение формулировать, умение применять, умение интерпретировать), естественнонаучная грамотность (умение объяснять, умение оценивать и применять, 
умение интерпретировать с научной точки зрения), финансовая грамотность, глобальные компетенции, креативное мышление.

Раздел 2. ПОМНИ, что:

Практико-ориентированное комплексное задание, направленное на формирование и оценку функциональной грамотности у школьников, должно содержать:

1. Единый или составной текст (сплошного, несплошного или смешанного формата, т.е. может включать такие элементы, как таблицы, карты, графики, диаграммы, рисунки, фотографии), описывающий ситуацию (три источника).

2. Вопросы (задания) (с закрытым или открытым ответом) различной степени сложности (низкий, средний, высокий).

3. Время, необходимое для выполнения задания.

\section{Раздел 3. СОБЛЮДАЙ:}

Правила оформления комплексного задания:

- Название задания;

- Класс;

- Доминирующая грамотность;

- Содержательная область оценки;

- Компетентностная область оценки;

- Контекст;

- Тип текста;

- Уровень сложности задания;

- Формат ответа;

- Объект оценки;

- Система оценивания.

Раздел 4. НЕ ЗАБЫВАЙ, что:

Для оформления задания можно использовать сервисы Web 2.0:

- Сервисы для создания интеллект-карт («MindMeister», «MindMaps»);

- Сервисы для создания «облака слов» («WordItOut», «Облакослов.рф»);

- Сервисы для создания «ленты времени» («WhenInTime», «Dipity»);

- Сервисы для создания ребусов («Rebus1.com», «Kvestodel»);

- Сервисы для создания коллажей («Mycollages.ru», «Collageonline»); 


\section{СОВРЕМЕННЫЕ ТЕХНОЛОГИИ:

- Сервисы для создания тестов и кроссвордов («OnlineTestPad») и др.

Можно применять различные современные педагогические подходы и технологии (приемы и методы) для формирования и оценки функциональной грамотности школьников:

1. Игровая технология (дидактическая игра, ролевая игра, познавательный квест);

2. Кейс-технология (решение ситуационной задачи, практического, научно-исследовательского, обучающего кейса);

3. Коммуникативная технология (облако слов, ребусы, кроссворд, кластер, кроссенс, круглый стол, дебаты);

4. Технология развития критического мышления («глухая» интеллекткарта, «Представьте, что Вы...», эссе, рецензия);

5. Технология проектно-исследовательской деятельности (скрайбинг, скетчноутинг, мини-проект, мини-исследование);

6. Технология проблемного обучения (мозговой штурм, творческий эксперимент) и др.

Домашнее задание для учащихся может быть сформулировано так:

1. Самостоятельно организуйте виртуальную экскурсию для одноклассников, представляя им архитектурные памятники своего родного края на тему...

2. Самостоятельно создайте страницы электронной энциклопедии «Юный историк» на тему...

3. Самостоятельно создайте электронный коллаж о ...

\section{РаздеЛ 5. ВЕРЬ В СЕБЯ И СВОИХ УЧЕНИКОВ!}

В заключении могу с уверенностью сказать, что представленная дидактическая памятка поможет учителю идти в ногу со временем и со своими учениками, сделает процесс обучения и решения реальных жизненных задач информативным, ярким, интересным, результативным и личностно значимым, будет способствовать росту функциональной грамотности учащихся. При этом будем помнить слова Сенеки: «Уча других, мы учимся сами»!

Для выявления трудностей возникающих в процессе формирования и оценки функциональной грамотности школьников была разработана система индикаторов, позволяющая своевременно выявить «узкие места» и планомерно устранить их. 
После реализации мероприятий «дорожной карты», направленной на формирование и оценку функциональной грамотности обучающихся, в МАОУ Домодедовский лицей №3 им. Героя Советского Союза Ю.П. Максимова ожидаются следующие результаты [4]:

1. Корректировка модели школы по формированию функциональной грамотности.

2. Создание условий для формирования функциональной грамотности обучающихся.

3. Пополнение банка метапредметных заданий.

4. Повышение уровня профессиональной компетентности педагогов по вопросу формирования функциональной грамотности учащихся.

5. Повышение качества образования, в частности, повышение уровня функциональной грамотности учащихся.

Подводя итоги, отметим, что международное исследование PISA оценивает, в первую очередь, возможность школьников руководствоваться здравым смыслом и логикой при выполнении нестандартных задач. Эксперты часто высказываются о том, что PISA оценивает не знания отдельных школьников и даже не качество образования в стране, а потенциал подрастающего поколения. А по большому счету - конкурентоспособность государства в будущем, и в наших силах преобразовать его к лучшему.

\section{Список литературы}

1. Гурьянова С.Ю. «Недаром помнит вся Россия про день Бородина!» (формирование функциональной грамотности на уроках истории) - М.: ИД «Первое сентября», 2022. URL: https://urok.1sept.ru/persons/416-006-476 (дата обращения: 07.01.2022).

2. Гурьянова С.Ю. Программа элективного курса по финансовой грамотности «Финансы: просто о сложном» // Научно-методический и теоретический журнал «Социосфера». 2017. №2. - с. 61-66. DOI: 10.24044/ sph.2017.2.13.

3. Ковалева Г.С. Что необходимо знать каждому учителю о функциональной грамотности // «Вестник образования России». - №16. 2019. - c.32-36. 
4. Кондратенко Е. Функциональная грамотность школьников: как развивать во втором полугодии. // Журнал «Справочник заместителя директора школы». - №1. - 2022.

5. Образовательная система «Школа 2100». Педагогика здравого смысла / под ред. А.А. Леонтьева. - М.: Баласс, 2003. - с.35.

6. Приказ Федеральной службы по надзору в сфере образования и науки Министерства просвещения РФ от 6 мая 2019 года № 590/219 «Об утверждении Методологии и критериев оценки качества общего образования в общеобразовательных организациях на основе практики международных исследований качества подготовки обучающихся (с изменениями на 24 декабря 2019 года)». [Электронный ресурс]. - URL: https://docs.cntd.ru/document/ 554691568? marker=6560IO (дата обращения 07.01.2022).

7. Результаты региональной оценки по модели PISA - 2021 (PISA for schools): Московская область. [Электронный ресурc]. - URL: https://mo. mosreg.ru/ download/document/9914520 (дата обращения 07.01.2022). 